To cite this document: Scarpellini, S., Valero-Gil, J., Rivera-Torres, P., \& Garcés-Ayerbe, C. (2017). Analysis of the generation of economic results in the different phases of the pro-environmental change process. Journal of Cleaner Production, 168. doi:10.1016/j.jclepro.2017.09.114

\title{
ANALYSIS OF THE GENERATION OF ECONOMIC RESULTS IN THE DIFFERENT PHASES OF THE PRO-ENVIRONMENTAL CHANGE PROCESS ${ }^{1}$
}

\author{
Sabina Scarpellini \\ University of Zaragoza - CIRCE Institute (Research Center for Energy Resources and \\ Consumptions) \\ Jesús Valero-Gil \\ University of Zaragoza - CIRCE Institute \\ Pilar Rivera-Torres \\ University of Zaragoza \\ Conchita Garcés-Ayerbe \\ University of Zaragoza
}

\begin{abstract}
Much of the research in environmental management has focused on analysing whether a firm's environmental efforts can be considered an argument in favour of or against its economic results, concluding that favourable results are not guaranteed, but depend on different aspects. This paper studies pro-environmental change processes in firms, focusing on how economic profit is generated during the process of changing to high degrees of environmental proactivity. Based on a sample of 303 Spanish firms located in the Aragon region, we classify four cluster categories of proenvironmental change. The description and comparative analysis of these categories leads us to consider that pro-environmental change is related to economic performance. The study's conclusions show that the economic benefits derived from pro-environmental change are greater when said change is more advanced or proactive.
\end{abstract}

Key words: Strategic environmental behaviour; Pro-environmental change; Economic performance; Process; Eco-innovation; Cluster analysis.

\footnotetext{
1 (C) <2017>. This manuscript version is made available under the CC-BY-NC-ND 4.0 license http://creativecommons.org/licenses/by-nc-nd/4.0/
} 


\section{INTRODUCTION}

In the advanced study of modern firms, the literature has focused extensively on analysing the determining factors of financial results. Different lines of research have tried to understand why apparently similar companies generate different performance values. One of these lines has considered that the inclusion of environmental care in firms is an important factor to take into account in the analysis of these differences. Indeed, in the firm context, future survival is related to identifying adaptable new business models, where sustainability appears as an interesting opportunity to gain competitive advantages (Hart, 2005). The evolution of companies towards more sustainable business models will undoubtedly require that they implement specific environmental strategies that facilitate the transition towards an environmental performance of zero emissions but at the same time facilitate the improvement of economic performance. Therefore, the relationship between environmental and economic performance in companies is a matter of great interest when designing political strategies for the promotion of sustainable business models.

Environmental performance in sustainable firms and its relation with financial performance has been analysed in depth since the end of the eighties. According to the literature, the likelihood of a winwin situation, in which both environmental and economic results improve, depends on how sustainable business model are designed. Specifically, the degree of proactivity of the environmental strategy implemented in the company conditions the possibility of obtaining economic benefits (Albertini, 2013; Rivera-Torres et al., 2015).

The relationship between environmental management and performance is one of the most analysed phenomena in environmental management literature. Since the establishment of the Porter Hypothesis (Porter, 1991; Porter and Van der Linde, 1995a, 1995b), many authors have tried to understand the economic effects of environmental efforts. In the last decade, studies by Albertini (2013) and Ambec \& Lanoie (2008) helped to clarify the answer to the question “Does it pay to be green?”, although basing their studies on different approaches. Specifically, Albertini (2013) provides a complete metaanalysis of the studies conducted on the topic in the last few years, affirming that there is a positive relationship between pro-environmental behaviour and economic performance, and providing a powerful framework in which to interpret previous studies that did not reach the same conclusions. Our research is positioned in line with this win-win perspective, paying special attention to the proenvironmental change process in firms and how economic benefits are generated during said process.

Although the literature contains numerous references to pro-environmental change in firms, there are few studies that describe the details of this process of change (Blum-Kusterer and Hussain, 2001; 
Chadee et al., 2011; Winn and Angell, 2000). Prior research highlighted the complexity of the transformation of organisations on a strategic level, especially when aimed at generating new, more sustainable processes, products and business models. Little is known, however, about what this transformation is like and its consequences (Iñigo and Albareda, 2016). One exception is found in Lee and Rhee (2007), who illustrate how environmental strategy changes and analyse the positive relationship between different environmental strategies involved in the change process and a firm's economic performance. Their results are inconclusive, because they do not find any differences in firm performance levels between their different stages of environmental strategy. These results are the main motivation for conducting this study, and following the final recommendations of these authors about sample, variables and measurements, we try to supplement their initial contributions.

Thus, our study particularly analyses the economic consequences of the environmental strategy throughout its evolution process towards the most advanced stages of environmental proactivity. More specifically, it examines how short-mid-term economic performance (SMEP) changes as a firm goes through the different stages of the pro-environmental change process. Therefore, we first study the pro-environmental change process in firms, attempting to discover whether change follows the same pathway for all firms, with similar and gradual growth in the scope and intensity of different environmental measures (process, product, management and/or supply chain), or whether there is no logical sequence in this process. Secondly, we analyse the relationship between environmental strategy and economic performance in each of the stages, in an attempt to find differences in this relationship. Our study concludes that different degrees of environmental strategy development that companies follow in a similar way can be considered, with different firm performance levels.

From a sample of 303 Spanish firms (collected in two successive phases), located in the region of Aragón, we classified pro-environmental change in four cluster categories. The description and comparative analysis of these categories leads us to consider the process of pro-environmental change as a process with four levels or stages of environmental strategy, along which firms can progress in both the scope and intensity of environmental measures. Collecting data in two phases for the empirical study allowed us to test for and verify the absence of bias, which is a very common characteristic of studies collecting data via surveys.

The descriptive analysis applied to the sample allows analysing the patterns of environmental behaviour in the change process and specific differences between them. This analysis not only considers operational aspects related to the protection of the environment, but also studies environmental measures that concern the business strategy of the company. The adoption of environmental measures is considered in four areas: process, product, management and supply chain. 
In addition, following Lee and Rhee (2007), we consider two dimensions to measure the adoption of environmental practices, scope and intensity. Finally, and this is one of the paper's most important contributions, we evaluate whether there is a relationship between phases of pro-environmental change and achievement of different firm performance levels. Our results show that environmental efforts lead to better economic results. This increase in performance is gradual, as the firm progresses through the pro-environmental change process.

Our results have important implications for management. The study's conclusions could offer arguments for firms that do not see the environmental requirement as mandatory, but as an opportunity to improve economic performance. Restructuring and including environmental aspects in firm's strategy, practitioners can achieve better benefits without damaging the relationship with the environment.

The paper begins with a theoretical discussion of environmental and change issues and the question of whether it pays to be green (Section 2). This literature review sets the stage for the empirical study (Section 3). The study's results (Section 4) precede the final sections (Sections 5 and 6), which focuses on discussion and conclusions.

\section{THEORETICAL FRAMEWORK}

\subsection{Environment and change towards sustainable business models}

Environmental improvement towards sustainable business models is associated to change, as it requires transformations in different areas of firms. The most commonly analysed changes in this regard are technological change (del Río González, 2009), change in business model strategy (Mokhlesian and Holmén, 2012) and change in the innovation model (Foster and Green, 2000). Sustainability, moreover, requires coordinated change, as change in a single business area is not sufficient (del Río González, 2009). The evolution towards sustainable business models will require changes in the areas related to processes, products, supply chain and management (Garcés-Ayerbe et al., 2016). Indeed, small adjustments or interventions are not enough; a greater transformation is required, affecting the entire organisation, its different strategic levels and its managers (Post and Altman, 1994).

The road to more sustainable business models is based on shifting towards new environmentallyfriendly positions (Bocken et al., 2014). This concept of change to new, more sustainable organisations has been studied in detail in the literature that analyses what is known as the "greening of business” or the transition to more sustainable firms. Schaefer and Harvey (1998) define this as a 
process started by firms that wish to be more environmentally responsible. Such changes seem to have much in common with organisational changes in general (Ronnenberg et al., 2011). They are not usually spontaneous and some firms have been encouraged to undertake a pro-environmental process due to pressure from different external sources, such as the market, legislation or society itself (Blum-Kusterer and Hussain, 2001; Post and Altman, 1994).

Lee and Rhee (2007) study how a firm's environmental strategy changes and evolves over time, establishing that change tends to be a movement towards more proactive positions, although this is not always a linear process. The process of changing to positions with a lesser environmental impact is seen as strategic, logical and complex (Adams et al., 2016). It is the pathway to environmental excellence, and is not free from interdependence, as the conduct and action taken in each phase have an impact on future phases of the process (Jabbour et al., 2013). Each step or phase of the environmental process is characterised by different types of impact-reducing measures, with numerous degrees of intensity and scope in their implantation (Lee and Rhee, 2007; Winn and Angell, 2000). For instance, process-focused measures related to corrective conduct such as end-of-pipe technologies are related to a reactive or not very advanced environmental stage (Buysse and Verbeke, 2003; Lee and Rhee, 2007). Firms in the last stages of environmental proactivity, however, are characterised by measures aimed at designing both new processes and products capable of generating environmental improvements through innovation (Bhargava and Welford, 1996; De Vries and Altenburg, 1995; Hart, 1995). We can thus conclude that the process will be described by a path in which some measures will be reactive, pursuant to legislation, while others will be more ambitious and preventive, in a more advanced stage, close to what is known as environmental proactivity.

\subsection{Does pro-environmental change pay?}

At the business level, the sustainability of the model means an intersection of the economic and environmental aspects that can be seen throughout the organization in the reduction in the use of resources (Liu et al., 2009). Having analysed the importance given in the literature to proenvironmental change towards sustainable business models, we now review significant literature on the topic of how this change is related to economic performance. The relationship between a firm's environmental management and its financial profits has drawn the attention of many scholars, because the sign of this relationship provides an argument in favour of or against environmental management itself (Lannelongue et al., 2015). Research reinforces the idea that the relationship between environmental and economic performance is determined by a positive function. However, there is still some controversy about the sign of this relationship. 
There are two major contradictory perspectives regarding environmental strategies and their impact on economic performance: win-lose and win-win (Hoffman, 2000; Moon et al., 2014). The win-lose perspective suggests that environmental protection incurs additional costs for firms, preventing or at least hindering economic productivity and thus undercutting competitiveness. The win-win perspective, more abundant in the literature, has received increasing attention in the last years, and it argues that better environmental performance provides cost reductions and an increase in sales, thus improving economic performance (Ambec and Lanoie, 2008; Aragón-Correa et al., 2008; Christmann, 2000; King and Lenox, 2002).

The debate is near its end, however, as the latest studies in the field incline the balance towards the win-win perspective, proposing new insights about the relationship. Thus, a recent meta-analysis of research on the topic concluded that the overall relationship between corporate environmental management and corporate financial performance is positive. The inconsistency of the results in the “does it pay to be green?” literature can also be attributed to the different proxies used by researchers in their empirical studies to measure environmental and financial performance (Albertini, 2013).

Our study is in line with the win-win perspective and proposes that sustainable business models enable managers to find innovative alternatives to existing business operations and generate greater economic returns. This line arose from the so-called "Porter Hypothesis", Porter (1991); Porter \& Van der Linde (1995a, 1995b), and others, claimed that environmental requirement is a tool that stimulates innovation towards less polluting and more efficient forms of production capable of generating competitive advantages. Following this line of argument, Hart (1995) links environmental issues to obtaining greater financial performance and argues that competitive advantages should be based on key capabilities and resources that facilitate an environmentally sustainable economic activity. Based on the Natural-Resource-Based view of the firm, this author argues that certain capabilities, such as “pollution prevention”, “product stewardship” and "sustainable development”, provide competitive advantages by reducing costs, anticipating competitors and improving stakeholder relations.

As knowledge has progressed in this field, these arguments have been supported and supplemented by numerous studies that focused on capabilities that provide competitive advantages based on green practices (e.g. Aragon-Correa and Sharma, 2003; Bansal, 2005; Russo, 2009). Also, much of this knowledge focused on providing empirical evidence for some of these competitive advantages, analysing how economic performance can be improved through pollution reduction (Guenster et al., 2011; King and Lenox, 2002; Klassen and Whybark, 1999), more advanced proactive environmental practices (Aragón-Correa et al., 2008; de Burgos-Jiménez et al., 2013; Rivera-Torres et al., 2015), 
environmental management systems (Christmann, 2000) or green innovation (Chen et al., 2006). According to these authors, such advantages include lower costs, higher quality in products and services, higher returns and an improved corporate image, among others.

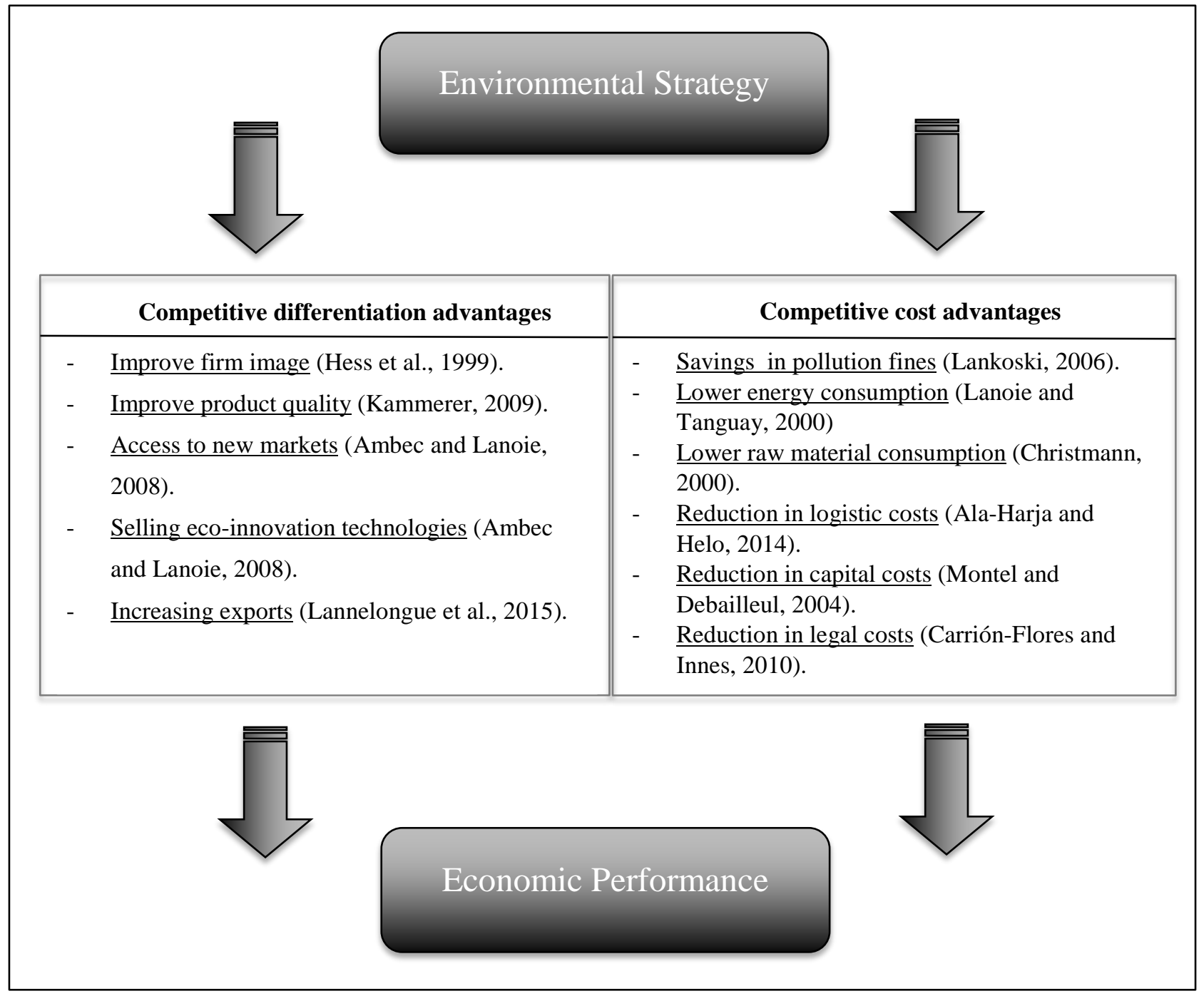

Figure 1: Main arguments detected in the literature in favour of the win-win perspective.

The review of the literature highlights two arguments in favour of a positive relationship between environmental investment and economic performance, those based on competitive differentiation advantages and those based on competitive cost advantages (Ambec and Lanoie, 2008; Christmann, 2000; Klassen and McLaughlin, 1996). Figure 1 summarises the main arguments detected in the literature in favour of the win-win perspective and the key company areas where environmental strategy improves economic performance.

There is a clear economic argument in favour of environmental efforts, but we also need to know how the economic improvement process is generated, and whether it is related to pro-environmental change. A firm will progress towards a more advanced environmental strategic position if it has or 
can acquire resources, to be transformed into instrumental competitive advantage capabilities that lead to greater returns (Backman et al., 2015). However, not all the environmental initiatives that comprise a firm's strategic position are likely to have the same economic effect on the organisation. Different types of environmental initiatives have unique and different effects for the firm (Gilley, 2000). In this regard, Christmann (2000) associated process-focused practices with cost advantages and product-focused with differentiation advantages. As pro-environmental change consists of an evolution in the adoption of different practices, the economic consequences will be different during different phases of the process. Gilley (2000) highlights the different relationships between performance and change, through process-oriented and product-oriented measures. Following a similar line, Segarra-Oña et al. (2015) empirically show how the process or product orientation of the firm is related to more environmentalism in its innovation process.

According to the literature review, a firm's environmental strategy, measured by the proenvironmental change process and based on patterns in the adoption of product, process, management and supply chain measures, improves its short-mid-term economic performance. This is possible thanks to a win-win situation in which both environmental and economic performance are improved. In addition, it is expected that the improvement in benefits will be different in the different stages of pro-environmental change, since they are a different scope and intensity in the adoption of environmental measures of product, process, management and supply chain. All this literature supports the following hypotheses:

Hypothesis 1A. The pro-environmental change process has a positive effect on the short-mid-term economic performance of a firm.

Hypothesis 1B. Pro-environmental change improves short- and mid-term economic performance in a different way throughout the process.

\section{RESEARCH METHODS}

To attain our objective, we begin with the information provided by a set of firms that operate in the autonomous region of Aragon. Among other issues of interest, the questionnaire referred to measurement of pro-environmental change in the last three years and change in economic performance in the same period. The questionnaire was validated by a panel of experts ${ }^{2}$. Considering

\footnotetext{
${ }^{2}$ The panel of experts comprised 7 people: three representatives of public administrations, two representatives of business associations, one academic expert and a corporate CEO. All of them worked in fields related to the business world and/or
} 
the strategic nature of the information required in the questionnaire, and in order to prevent selection bias in the sample, we provided the opportunity to respond privately (not face-to-face with the interviewer) and/or anonymously (as firm identification was optional), guaranteeing full confidentiality and specifically referring to current data protection legislation. The interviewees were also told that the objective of the questionnaires was purely academic. The following section provides a description of the sample, the study variables and the methodology used.

\subsection{Sample}

The unit of analysis includes firms established in Spain, specifically in the Region of Aragon, with at least 5 employees. A total of 2,996 questionnaires were sent in June $2013^{3}$, addressed to the person in charge of the environmental area or, if there was no such person, to the CEO. We sent the survey again in October 2013 with monitoring via telephone, highlighting the sectors and firm sizes that fit the least with the real structure of the population. Three months later, we obtained a final sample of 303 valid observations, giving a response rate of $10.11 \%$, similar to that found in other empirical studies of this kind. The firms in the sample are distributed in four sectors (Agriculture, Forestry and Fishing Sector - 8.9\%, Industrial Sector - 40.6\%, Construction - 10.2\% and Service Sector - 40.3\%) and four size categories, according to number of employees (5 to $10-33.7 \%, 11$ to $50-45.2 \%, 51$ to $250-16.8 \%$ and More than $250-4.3 \%)^{4}$.

\subsection{Measurement}

\subsubsection{Pro-environmental change}

We generated a pool of measurement items from the literature on environmental management, which measure the degree of pro-environmental change in firms over the last three years; a set of variables was designed that synthesises both intensity and scope. The selection of these indicators started with those used in other studies (Aragón-Correa, 1998; Huang et al., 2014; Lee and Rhee, 2007; MurilloLuna et al., 2008), as well as the assessments provided by the panel of experts. A set of 14 proenvironmental change indicators (Table 1) were used, 4 to measure change in processes, 3 to measure change in products, 4 to measure change in management and 3 to measure change in the supply chain. Based on the opinion of the interviewed firm representative, these indicators enable us to quantify the degree of application of regular pro-environmental measures in the last 3 years, using a Likert scale

the environment. Using a Likert scale from 0 to 10, the experts were asked to evaluate the ease of comprehension and relevance of each of the survey's items.

${ }^{3}$ The SABI database was used to collect information about these firms and the contact data were obtained from their websites and telephone calls.

${ }^{4}$ These distributions are not substantially different from those of the population of firms in the SABI database. 
from 0 to 10, where 0 is "no measure has been applied" and 10 means "many measures have been applied”.

\subsubsection{Intensity of pro-environmental change}

The 14 indicators directly measure the intensity with which each of the 14 types of measures have been applied on a scale from 0 to 10 , where 0 is no intensity and 10 is very high intensity. These led to partial and total intensity measures. The former measure the mean of the items, from 0 to 10 , for each of the four groups of pro-environmental change (process, product, management and supply chain). The second type of measure focuses on measuring total intensity regarding pro-environmental change over the last few years (from 0 to 10), calculated by the mean of the 14 items included in the questionnaire.

\subsubsection{Scope of pro-environmental change}

As well as considering intensity in the application of measures, it is interesting to evaluate the scope and diversity of the measures applied. In this respect, different intermediate variables were developed to measure the partial and total scope of pro-environmental change. The former evaluates the scope of the four types of measure (process, product, management and supply chain). The four partial variables have values of 0-4 for process and management measures and 0-3 for product and supply chain measures, according to the variety of measures applied for each type (thus coinciding with the number of items of each type). The second variable measures total variety in the implantation of proenvironmental change, with values from 0 to 4 . In this case what is counted is the scope of different types of variable, referring to the number of areas in which such measures are applied.

\subsubsection{Short-mid-term economic performance}

A series of items were used to measure results associated to pro-environmental change, with consideration of the possibility of attaining cost-related and differentiation-related advantages for the firm, considering recent literature (e.g. Antonietti and Marzucchi, 2014; Lai and Wong, 2012; Lannelongue et al., 2015). Specifically, we used a set of 7 items (Table 1): 3 to measure efficiency results, 3 to measure market results and 1 to measure stakeholder relations results. Based on the opinion of the person completing the survey, these results were assessed using a Likert scale from 0 to 10 , where 0 means "in no case” and 10 means "to a great extent". 
Table 1. Main items used to measure the variables.

PEC Pro-Environmental Change Indicators

The following has occurred in your firm over the last THREE YEARS:

\section{PROCESS}

PEC_1

...new low-consumption or low environmental impact equipment/machinery (water, materials, electric power, heating, etc.) has been installed.

PEC_2

...operative procedures or methods have been changed to reduce the consumption of resources and/or energy or reduce environmental impact.

PEC_3

...new action has been taken to correct pollutants (water purifiers, waste processing or recycling, filters, storage systems, etc.).

PEC_4

...new systems have been installed to use and/or generate renewable sources of energy (solar panels, photovoltaic panels, wind turbines, biomass, etc.).

\section{PRODUCT}

PEC_5

PEC_6

PEC_7

...the design of products or components has been changed to reduce the use of materials or recourses and/or to replace them with other less polluting materials (eco-design).

...the design of products has been changed to facilitate recycling or reuse.

...new environmental criteria have been considered in the design and/or manufacture of packaging, etc. (ecodesign).

MANAGEMENT

PEC_8

...new resources have been spent on training employees in or increasing their awareness of environmental issues and/or innovation.

PEC_9

...jobs have been re-designed to improve the firm’s environmental impact.

PEC_10

...people have been appointed to be responsible for environmental affairs in the firm.

PEC_11

...investments have been made in R\&D to improve the firm's environmental impact.

\section{SUPPLY CHAIN}

PEC_12

...new measures have been applied in supply and stock management systems aimed at improving the firm’s environmental impact.

PEC_13

...new measures have been applied in distribution and marketing systems aimed at improving the firm's environmental impact.

PEC_14

...product labelling/instructions have been changed to show environmental aspects or inform consumers of appropriate means of disposal.

SMEP Short-Mid-Term Economic Performance

As a result of your above referenced pro-environmental change...

\section{COST ADVANTAGES}

SMEP_1 …variable costs have been reduced.

SMEP_2 ‥the company’s productivity has improved.

SMEP_3 ...the company's returns have increased.

\section{DIFFERENTIATION ADVANTAGES}

SMEP_4 ...your products are differentiated from those of your competitors.

SMEP_5 …the company’s market share has grown (current market).

SMEP_6 ...the markets targeted by the company have increased (new markets).

SMEP_7

...stakeholder (clients, employees, shareholders, nearby communities, associations, etc.) relations have improved. 


\subsubsection{Controlling biases}

Our study adopted ex-ante measures in the research design stage to prevent selection bias and common method (Chang et al., 2010; Podsakoff et al., 2003; Podsakoff and Organ, 1986). Regarding selection bias, and following Armstrong \& Overton (1977), we compared early and late respondents in the observed variables. The tests to compare the answers of early versus late respondents were not significant at 0.03 . Selection bias was therefore not a serious problem in this research. As noted by Chang et al. (2010; p:180), “common method variance is more likely to emerge in models that are overly simple”. Our model include a complex relationship (cluster analysis and structural model), so the tests of our hypothesis may not be much affected by common method bias; in other words, our “own theoretical model” was likely to reduce common method variance.

\subsection{Statistical Methodology}

Environmental management literature has developed several types of environmental strategy that firms adopt to deal with environmental issues (e.g. Hunt and Auster, 1990; Murillo-Luna et al., 2008; Roome, 1992). These studies usually distinguish between two extreme positions: environmental proactivity and environmental reactivity. Our empirical study refers to an exploratory analysis aimed at characterising the 303 firms in the sample according to degree of proactivity in pro-environmental change. Following the methodology proposed by Lee and Rhee (2007), we performed a cluster analysis in which the grouping variables were degree of intensity and scope of the pro-environmental change measures applied by the firms in their production cycles. Cluster analysis is often used to identify patterns of behaviour in firms' environmental strategies (Aragón-Correa et al., 2008; Backman et al., 2015; Fernández Gago and Nieto Antolín, 2004). Indeed, some studies use categorisation through cluster analysis to measure the relationship between environmental proactivity and performance (Alvarez Gil et al., 2001; Carmona-Moreno et al., 2004).

After obtaining the different patterns of pro-environmental change, different analyses of variance (equality of mean vector) were performed and the results of the respective Duncan tests (multiple range) were analysed in order to obtain a final characterisation. Once the environmental behaviour groups were developed, we analysed the relationship between the levels of proactivity in the firm, measured troughs belonging to one of the previously developed four environmental strategies, and short-mid-term economic performance. We then used confirmatory factor analysis to examine the dimensional structure of the theoretical constructs involved in our "Short-mid-term economic performance” hypothesis. 


\section{RESULTS}

The aforementioned cluster analysis shows that there are four different groups with very significant distinctions. Table 2 shows the differences between groups based on the average intensity of all the items used to describe the firm's environmental proactivity. This table shows these differences between groups, but now based on partial and total scope and the average intensity of the implantation of pro-environmental change measures. Also, based on the analysis of variance and the Duncan test, these first results show great significance in the definition of the four clusters, both individual and in the aggregate, so a high degree of consistency is ensured in the subsequent description of the groups.

Thanks to the evolution of the mean intensity values, shown on Table 2, we can affirm that each of the four cluster groups has important intrinsic descriptive characteristics that are worth discussing. The firms in the first group, called Laggard Proactive, present very low intensity, with scope limited to process measures. Initiated Proactive firms significantly increase the mean intensity value, together with scope, by adding Management-related measures. The firms in the Advanced Proactive group show a further significant increase in intensity, plus total scope, by measures affecting the four study fields. Finally, the Eco-innovative group is primarily characterised by significant increases in intensity in all measures, with the total scope acquired in the previous group in relation to proenvironmental change.

Continuing with the analysis of the mean intensity values shown on Table 2, it also shows how economic performance improved in all aspects related to cost advantages and differentiation. For each cluster group, it shows how economic performance has evolved in the last three years. In the case of Laggard Proactive firms, the presence of a low level in the pro-environmental change measures results in practically no improvement in short-mid-term economic performance. The presence of changes in process and management found in Initiated Proactive firms shows limited improvement in performance. This improvement is associated fundamentally with the Competitive cost advantages and much less with Competitive differentiation advantages. The following group, Advanced Proactive firms, presents a very significant increase in performance; as they apply product and supply chain measures, the improvement is found in results related to both Cost and Differentiation advantages. Eco-innovative firms improve mean performance values on all levels, by implanting the four types of measure. 
Table 2. Description of Cluster Groups

\begin{tabular}{|c|c|c|c|c|c|c|c|}
\hline & $\begin{array}{c}\begin{array}{c}\text { Laggard } \\
\text { Proactive } \\
\text { n=31 }\end{array} \\
\end{array}$ & 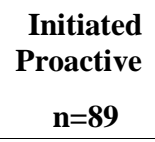 & $\begin{array}{c}\begin{array}{c}\text { Advanced } \\
\text { Proactive } \\
\text { n=124 }\end{array} \\
\end{array}$ & $\begin{array}{c}\text { Eco- } \\
\text { Innovative } \\
n=59 \\
\end{array}$ & & & $\begin{array}{c}\text { Duncan } \\
\text { test }\end{array}$ \\
\hline Pro-Environmental Change & $\bar{x}_{1}$ & $\bar{x}_{2}$ & $\bar{x}_{3}$ & $\bar{x}_{4}$ & $\bar{X}$ & ANOVA & \\
\hline \multicolumn{8}{|l|}{ PROCESS } \\
\hline New equipment & 1.26 & 3.98 & 5.80 & 8.86 & 5.29 & $64.29 * * *$ & $\dagger$ \\
\hline Change methods & 1.29 & 4.80 & 6.68 & 9.02 & 6.00 & $97.64 * * *$ & $\dagger$ \\
\hline Correct pollutants & 0.77 & 3.67 & 5.85 & 8.39 & 5.08 & $69.13^{* * *}$ & $\dagger$ \\
\hline Renewable energy & 0.23 & 1.08 & 2.84 & 5.91 & 2.48 & $27.92 * * *$ & $\begin{array}{l}\bar{x}_{1}= \\
\bar{x}_{2}\end{array}$ \\
\hline \multicolumn{8}{|l|}{ PRODUCT } \\
\hline Reduce materials & 0.04 & 2.26 & 5.78 & 8.93 & 4.71 & $123.90 * * *$ & $\dagger$ \\
\hline Recycling/Reusing & 0.04 & 1.56 & 4.96 & 8.63 & 4.07 & $122.92 * * *$ & $\dagger$ \\
\hline Packaging & 0.00 & 1.61 & 5.14 & 8.16 & 4.01 & $89.22 * * *$ & $\dagger$ \\
\hline \multicolumn{8}{|l|}{ MANAGEMENT } \\
\hline Training employees & 0.59 & 4.61 & 6.50 & 8.87 & 5.78 & $104.79 * * *$ & $\dagger$ \\
\hline Change jobs & 0.07 & 1.96 & 5.02 & 7.98 & 4.05 & $101.12 * * *$ & $\dagger$ \\
\hline Responsible & 0.29 & 3.68 & 6.56 & 8.91 & 5.51 & $72.36 * * *$ & $\dagger$ \\
\hline R\&D & 0.00 & 1.73 & 4.74 & 7.78 & 3.85 & $72.03 * * *$ & $\dagger$ \\
\hline \multicolumn{8}{|l|}{ SUPPLY CHAIN } \\
\hline Supply/Stock & 0.00 & 1.74 & 5.28 & 7.71 & 4.08 & $116.03 * * *$ & $\dagger$ \\
\hline Distribution & 0.15 & 1.62 & 5.24 & 7.94 & 4.16 & $112.09 * * *$ & $\dagger$ \\
\hline Labelling & 0.16 & 1.30 & 4.18 & 7.72 & 3.45 & $72.22 * * *$ & $\dagger$ \\
\hline $\begin{array}{l}\text { Scope of Pro-Environmental } \\
\text { Change (1-4) }\end{array}$ & 0.97 & 2.97 & 3.59 & 3.51 & 3.12 & $98.16^{* * *}$ & $\begin{array}{l}\bar{x}_{3}= \\
\bar{x}_{4}\end{array}$ \\
\hline $\begin{array}{l}\text { Intensity of Pro-Environmental } \\
\text { Change (0-10) }\end{array}$ & 0.43 & 2.67 & 5.40 & 8.28 & 4.65 & $783.64 * * *$ & $\dagger$ \\
\hline \multicolumn{8}{|l|}{$\begin{array}{l}\text { Short-Mid-Term Economic } \\
\text { Performance }\end{array}$} \\
\hline \multicolumn{8}{|l|}{ COST ADVANTAGES } \\
\hline Cost savings & 0.69 & 2.91 & 5.59 & 7.73 & 4.76 & $73.48^{* * *}$ & $\dagger$ \\
\hline Increase productivity & 0.46 & 2.81 & 5.74 & 7.71 & 4.75 & $83.77 * * *$ & $\dagger$ \\
\hline Increase profitability & 0.73 & 2.85 & 5.45 & 7.49 & 4.62 & $62.38 * * *$ & $\dagger$ \\
\hline \multicolumn{8}{|c|}{ DIFFERENTIATION ADVANTAGES } \\
\hline Differentiation & 0.30 & 2.28 & 5.70 & 7.92 & 4.70 & $72.92 * * *$ & $\dagger$ \\
\hline Increase market share & 0.23 & 1.36 & 4.64 & 6.63 & 3.60 & $78.91^{* * *}$ & $\dagger$ \\
\hline Access to new markets & 0.16 & 1.80 & 4.89 & 7.08 & 3.92 & $58.41^{* * *}$ & $\dagger$ \\
\hline Stakeholders relationship & 0.50 & 2.48 & 5.69 & 7.94 & 4.69 & $83.84 * * *$ & $\dagger$ \\
\hline
\end{tabular}

In view of the ANOVA results (Table 2), we do not reject Hypothesis 1A, as they confirm significant differences in the level of short-mid-term economic performance for the different groups. In addition, we can see how, for all SMEP variables, the mean values for each group grow by increasing the level of environmental proactivity between groups; cost reduction is the most important benefit factor and market share growth the least important. Furthermore, for each environmental pattern there is an SMEP variable with a high value of achievement, but in any case the reactive approach (Laggard 
Proactive) presents no improvement in economic performance (mean value close to 0/10). On the other hand, the most innovative behaviour (in the Eco-innovative group) obtains important improvements in SMEP variables (mean values of 6.63-7.94/10). In view of this differences we observed the results of the Duncan test, which compares the differences in the variables for each pair of categories. The results, which find significant differences for each pair of categories, lead us not to reject Hypothesis 1B, showing that the more advanced the process of pro-environmental change, the greater the improvement in economic results.

With the aim of obtaining more evidence in favour of the Hypotheses, a structural equation model was estimated with a unique latent variable ${ }^{5}$, specifically a MIMIC model (multiple items and multiple causes). As it is an exogenous variable, a categorical variable that describes environmental behaviour and degree of environmental proactivity was estimated. Thus, we decided to estimate 3 dummy variables (where a value of 1 refers to belonging to a particular group: "Initiated Proactive”, “Advanced Proactive” or "Eco-Innovative”) and the cluster control (when all dummy variables are 0 ) is the most reactive group ("Laggard Proactive”). The model presents reasonable adjustment, with $\chi 2(32)=200.18, \mathrm{RMSEA}=0.079, \mathrm{SRMR}=0.040$ and $\mathrm{CFI}=0.900$. Table 3 shows the nonstandardised coefficients (direct and indirect effects) taking “Laggard Proactive” as the control group. In view of these coefficients, we achieve empirical evidence that enables us not to reject hypothesis $\mathrm{H} 1 \mathrm{~A}$, both in terms of the latent variable (1.74-4.42-6.23), and in terms of individual indicators, with all coefficients significant at $1 \%$. We also see that the differences increase when degree of proactivity is greater. This evidence enables us not to reject hypothesis H1B.

\section{DISCUSSION}

Our results are mainly framed in the previous literature which empirically analyses the win-win perspective in the relationship between pro-environmental behaviour and economic performance (e.g. Ambec and Lanoie, 2008; Aragón-Correa et al., 2008; Christmann, 2000; King and Lenox, 2002). This research contributes to knowledge on this topic, providing empirical evidence that firm's proenvironmental change towards sustainable business models is a systematic process that progressively increases scope and intensity in the adoption of environmental practices and that improves economic performance along the way. In this systematic process of pro-environmental change firms first adopt process and management measures and later complement them with product and supply chain

\footnotetext{
${ }^{5}$ In the case of short-mid-term economic performance items, the results of the confirmatory factor analysis suggest the presence of one dimension $(\chi 2[14]=135.77, \mathrm{RMSEA}=0.072$, SRMR $=0.053$ and $\mathrm{CFI}=0.903)$; both the factorial loads $(\lambda>0.81)$ and the percentages of explained variance (R2>0.66) present appropriate values.
} 
measures. As a result of this systematic process, companies first obtain advantages in costs and later also advantages by differentiation.

This procedure, in line with the "Porter Hypothesis" (Porter, 1991; Porter and Van der Linde, 1995a, 1995b), suggests that firms advance bit by bit towards less polluting and more efficient forms of production capable of generating competitive advantages. In addition, we confirm that due to the main arguments detected in the literature in favour of the win-win perspective (Figure 1 references), environmental efforts can be seen as an opportunity to improve the firm’s performance.

Table 3. Results of the Structural Models

\begin{tabular}{lccc}
\hline & Initiated Proactive $\mathbf{n = 8 9}$ & $\begin{array}{c}\text { Advanced Proactive } \\
\mathbf{n = 1 2 4}\end{array}$ & \begin{tabular}{c} 
Eco-Innovative n=59 \\
\hline
\end{tabular} \\
\hline $\begin{array}{l}\text { Direct Effects } \\
\text { Short-Mid-Term Economic }\end{array}$ & & $\beta$ & $\beta$ \\
Performance & $1.74^{* * *}$ & & \\
\hline Total Effects & & $4.42^{* * *}$ & $6.23^{* * *}$ \\
Cost savings & $1.74^{* * *}$ & & \\
Differentiation & $2.13^{* * *}$ & $4.42^{* * *}$ & $6.23^{* * *}$ \\
Increase productivity & $1.95^{* * *}$ & $5.42^{* * *}$ & $7.68^{* * *}$ \\
Increase profitability & $1.90^{* * *}$ & $4.96^{* * *}$ & $7.03^{* * *}$ \\
Increase market share & $1.94^{* * *}$ & $4.83^{* * *}$ & $6.85^{* * *}$ \\
Access to new markets & $2.01^{* * *}$ & $4.93^{* * *}$ & $6.98^{* * *}$ \\
Stakeholder relations & $2.03^{* * *}$ & $5.10^{* * *}$ & $7.23^{* * *}$ \\
\hline
\end{tabular}

Group control "Laggard Proactive ( $n=31)$ "

$\chi^{2}(32)=200.18, R M S E A=0.079, S R M R=0.040$ and $C F I=0.900$

$\beta$ : Unstandardized coefficients.

*** Significant at $1 \%$

We confirm a change model that follows the theoretical ideas set out in the previous literature. The process starts by firms that wish to be more environmentally responsible (Schaefer and Harvey, 1998). On the other hand, the firms in the last group of the pro-environmental change process are characterised by designing new measures capable of generating environmental advancements through innovation (Bhargava and Welford, 1996; De Vries and Altenburg, 1995; Hart, 1995). These results are also in line with Gilley (2000), who suggested that each type of pro-environmental change measure has a different effect on a firm's economic performance. Thus, we show that every process stage is related with a different type of measure, beginning with simple measures related to process and, in advanced stages, incorporating measures in line with product and supply chain. In turn, we show that the different pro-environmental change stages lead to different economic performance improvements. 
Finally, our empirical analysis supplements those conducted by Lee and Rhee (2007), who empirically found no significance in the relationship between different stages of pro-environmental change and economic performance. This was partly due to these author's final recommendations regarding the reasons why their study did not obtain such empirical results. Following their advice in relation to variables, sample and measurement methodology, we achieve an interesting empirical justification of the positive relationship.

\section{CONCLUSIONS}

This study considers the strategic environmental behaviour of firms in order to detect homogeneous patterns according to degree of proactivity. The cluster analysis applied to a sample of 303 Spanish firms showed interesting results, identifying four well differentiated behaviour patterns with significantly different characteristics, evaluating whether belonging to one group or another is decisive in the achievement of better economic performance, or in other words, whether proactive environmental behaviour is related to good economic performance.

The empirical evidence found leads to important conclusions, because we find that proactive strategies improve short-mid-term economic performance, with significant cost reductions, important returns, better market positioning and differentiation strategies and better stakeholder relations. Thus, we confirm that the firm can adopt four strategies when it addresses aspects of environmental management, as a reactive approach that aims to repair environmental impact, to meet applicable legislation (at best), a proactive approach based on voluntarily taking steps to reduce (rather than correct) the impact on the environment and finalising with the most advanced of the approaches, trying to minimize environmental impact by increasing the intensity of the measures adopted. The choice of advanced behaviour can be vital for obtaining returns from increasingly common practices related to environmental issues.

This study has important implications for management, which need to be taken into account. In the first place, it considers environmental efforts to be a tool to achieve important cost and competitive advantages. Secondly, it uses an interesting methodological approach to evaluate the relationship between environmental efforts and economic results, using techniques sometimes employed to measure environmental behaviour in the firm. Finally, the study also shows the different business performance implications for every step in the pro-environmental change process, confirming the more reduced economic effects of the initial phases, and important economic improvement found in the eco-innovative phase. Firms should know that it is important to follow the 4-step model of change, but the goal should always be the last stages, in order to see an improvement in economic 
performance. In this regard, it is important to offer verifiable arguments so that practitioners move towards these changes, which lead to new sustainable business models.

The results of our research should be analysed with caution due to some of the limitations of our study, which suggest important future lines of research. The first limitation refers to the selection of performance measures. Although they were obtained considering the results of previous studies that aimed to measure financial and organisational performance, they could be improved in the future by including a specific analysis of whether the most proactive environmental behaviour improves environmental performance.

Furthermore, the sample was a regional one. Although it was representative of the study population, it represents a limited geographic area in Europe. Although the results could be extrapolated to areas with similar industrial characteristics, they should be confirmed with samples from more regions. This leads to the need for future research to replicate our analysis with alternative samples from other geographic areas and different characteristics.

\section{ACKNOWLEDGMENT}

This study was supported the Spanish Ministry of Economy and Competitiveness [ECO2013-45599R, ECO2013-48496-C4-3-R and ECO2016-77843-P]; and the Gobierno de Aragón - Fondo Europeo de Desarrollo Regional research groups [CREVALOR and “Socioeconomía de la energía y la sostenibilidad - S128”].

\section{REFERENCES}

Ala-Harja, H., Helo, P., 2014. Green supply chain decisions - Case-based performance analysis from the food industry. Transp. Res. Part E Logist. Transp. Rev. 69, 97-107. doi:10.1016/j.tre.2014.05.015

Albertini, E., 2013. Does Environmental Management Improve Financial Performance? A MetaAnalytical Review. Organ. Environ. 26, 431-457. doi:10.1177/1086026613510301

Alvarez Gil, M.J., Burgos Jimenez, J., Céspedes Lorente, J.J., 2001. An analysis of environmental management , organizational context and performance of Spanish hotels. Omega 29, 457-471.

Ambec, S., Lanoie, P., 2008. Does It Pay to Be Green? A Systematic Overview. Acad. Manag. Perspect. 22, 45-62. doi:10.5465/AMP.2008.35590353 
Antonietti, R., Marzucchi, A., 2014. Green tangible investment Strategies and export eerformance: A firm-level investigation. Ecol. Econ. 108, 150-161. doi:10.2139/ssrn.2331970

Aragón-Correa, J.A., 1998. Strategic proactivity and firm approach to the natural environment. Acad. Manag. J. 41, 556-567. doi:10.2307/256942

Aragón-Correa, J.A., Hurtado-Torres, N., Sharma, S., García-Morales, V.J., 2008. Environmental strategy and performance in small firms: A resource-based perspective. J. Environ. Manage. 86, 88-103. doi:10.1016/j.jenvman.2006.11.022

Aragón-Correa, J.A., Sharma, S., 2003. A contingent resource-based view of proactive corporate environmental stretagey. Acad. Manag. Rev. 28, 71-88. doi:10.5465/AMR.2003.8925233

Armstrong, J.S., Overton, T.S., 1977. Estimating Nonresponse Bias in Mail Surveys. J. Mark. Res. 14, 396. doi:10.2307/3150783

Backman, C.A., Verbeke, A., Schulz, R.A., 2015. The Drivers of Corporate Climate Change Strategies and Public Policy: A New Resource-Based View Perspective. Bus. Soc. 1-31. doi:10.1177/0007650315578450

Bansal, P., 2005. Evolving sustainably: a longitudinal study of corporate sustainable development. Strateg. Manag. J. 26, 197-218.

Bhargava, S., Welford, R., 1996. Corporate strategy and the environment: the theory, in: Welford, R. (Ed.), Corporate Environmental Management: Systems and Strategies. pp. 13-26.

Blum-Kusterer, M., Hussain, S.S., 2001. Innovation and corporate sustainability: An investigation into the process of change in the pharmaceuticals industry. Bus. Strateg. Environ. 10, 300-316. doi:10.1002/bse.300

Bocken, N.M.P., Short, S.W., Rana, P., Evans, S., 2014. A literature and practice review to develop sustainable business model archetypes. J. Clean. Prod. 65, 42-56. doi:10.1016/j.jclepro.2013.11.039

Buysse, K., Verbeke, A., 2003. Proactive environmental strategies: A stakeholder management perspective. Strateg. Manag. J. 24, 453-470. doi:10.1002/smj.299

Carmona-Moreno, E., Céspedes-Lorente, J., De Burgos-Jiménez, J., 2004. Environmental strategies in spanish hotels: contextual factors and performance. Serv. Ind. J. 24, 101-130. 
doi:10.1080/0264206042000247786

Carrión-Flores, C.E., Innes, R., 2010. Environmental innovation and environmental performance. J. Environ. Econ. Manage. 59, 27-42.

Chadee, D., Wiesner, R., Roxas, B., 2011. Environmental sustainability change management in SMEs: learning from sustainability champions. Int. J. Learn. Chang. 5, 194. doi:10.1504/IJLC.2011.045068

Chang, S.-J., van Witteloostuijn, A., Eden, L., 2010. From the Editors: Common method variance in international business research. J. Int. Bus. Stud. 41, 178-184. doi:10.1057/jibs.2009.88

Chen, Y.-S., Lai, S.-B., Wen, C.-T., 2006. The influence of green innovation performance on corporate advantage in Taiwan. J. Bus. Ethics 67, 331-339.

Christmann, P., 2000. Effects of “best practices” of environmental management on cost advantage: The role of complementary assets. Acad. Manag. J. 43, 663-680.

de Burgos-Jiménez, J., Vázquez-Brust, D., Plaza-Úbeda, J.A., Dijkshoorn, J., 2013. Environmental protection and financial performance: an empirical analysis in Wales. Int. J. Oper. Prod. Manag. 33, 981-1018. doi:10.1108/IJOPM-11-2010-0374

De Vries, W., Altenburg, U., 1995. Milieumarketing, Stenfert K. ed. Houten.

del Río González, P., 2009. The empirical analysis of the determinants for environmental technological change: A research agenda. Ecol. Econ. 68, 861-878. doi:10.1016/j.ecolecon.2008.07.004

Fernández Gago, R., Nieto Antolín, M., 2004. Environmental management and strategic positioning of Spanish manufacturing industries. Bus. Strateg. Environ. 13, 33-42. doi:10.1002/bse.391

Foster, C., Green, K., 2000. Greening the innovation process. Bus. Strateg. Environ. 9, 287-303. doi:10.1002/1099-0836(200009/10)9:5<287::AID-BSE256>3.0.CO;2-7

Garcés-Ayerbe, C., Scarpellini, S., Valero-Gil, J., Rivera-Torres, P., 2016. Proactive environmental strategy development: from laggard to eco-innovative firms. J. Organ. Chang. Manag. 29, 1118-1134. doi:10.1108/JOCM-05-2016-0081

Gilley, K.M., 2000. Corporate Environmental Initiatives and Anticipated Firm Performance: The 
Differential Effects of Process-Driven Versus Product-Driven Greening Initiatives. J. Manage. 26, 1199-1216. doi:10.1177/014920630002600607

Guenster, N., Bauer, R., Derwall, J., Koedijk, K., 2011. The Economic Value of Corporate EcoEfficiency. Eur. Financ. Manag. 17, 679-704.

Hart, S.L., 2005. Capitalism at the crossroads : the unlimited business opportunities in solving the world's most difficult problems. Wharton School.

Hart, S.L., 1995. A natural-resource-based view of the firm. Acad. Manag. Rev. 20, 986-1014.

Hess, J., Kaouris, M., Williams, J., 1999. Environmental management: What ISO 14000 brings to the table, in: Crognale, G. (Ed.), Environmental Quality Management: The 21st Century Perspective. Upper Saddle River, pp. 317-352. doi:10.1002/tqem.3310040403

Hoffman, A.J., 2000. Competitive Environmental Strategy: A Guide To The Changing Business Landscape.

Huang, Y., Wong, Y., Yang, M., 2014. Proactive environmental management and performance by a controlling family. Manag. Res. Rev. 37, 210-240. doi:10.1108/MRR-09-2012-0196

Hunt, C., Auster, E., 1990. Proactive Environmental Management: Avoiding the Toxic Trap. MIT Sloan Manag. Rev. 31, 7-18.

Iñigo, E.A., Albareda, L., 2016. Understanding sustainable innovation as a complex adaptive system: a systemic approach to the firm. J. Clean. Prod. 126, 1-20. doi:10.1016/j.jclepro.2016.03.036

Jabbour, C.J.C., Sarkis, J., Jabbour, A.B.L. de S., Govindan, K., 2013. Understanding the process of greening of Brazilian business schools. J. Clean. Prod. 61, 25-35. doi:10.1016/j.jclepro.2013.05.001

Kammerer, D., 2009. The effects of customer benefit and regulation on environmental product innovation.: Empirical evidence from appliance manufacturers in Germany. Ecol. Econ. 68, 2285-2295.

King, A., Lenox, M., 2002. Exploring the locus of profitable pollution reduction. Manage. Sci. 48, 289-299. 
Klassen, R.D., McLaughlin, C.P., 1996. The Impact of Environmental Management on Firm Performance. Manage. Sci. 42, 1199-1214. doi:10.1287/mnsc.42.8.1199

Klassen, R.D., Whybark, D.C., 1999. The impact of environmental technologies on manufacturing performance. Acad. Manag. J. 42, 599-615.

Lai, K., Wong, C.W.Y., 2012. Green logistics management and performance: Some empirical evidence from Chinese manufacturing exporters. Omega 40, 267-282. doi:10.1016/j.omega.2011.07.002

Lankoski, L., 2006. Environmental and economic performance: The basic links. Manag. Bus. Case Sustain. Integr. Soc. Envir 1, 29-46.

Lannelongue, G., Gonzalez-Benito, J., Gonzalez-Benito, O., 2015. Input, Output, and Environmental Management Productivity: Effects on Firm Performance. Bus. Strateg. Environ. 24, 145-158. doi:10.1002/bse.1806

Lanoie, P., Tanguay, G., 2000. Factors leading to green profitability. Greener Manag. Int. 2000, 3850.

Lee, S.Y., Rhee, S.-K., 2007. The change in corporate environmental strategies: a longitudinal empirical study. Manag. Decis. 45, 196-216. doi:10.1108/00251740710727241

Liu, Q., Li, H., Zuo, X., Zhang, F., Wang, L., 2009. A survey and analysis on public awareness and performance for promoting circular economy in China: A case study from Tianjin. J. Clean. Prod. 17, 265-270. doi:10.1016/j.jclepro.2008.06.003

Mokhlesian, S., Holmén, M., 2012. Business model changes and green construction processes. Constr. Manag. Econ. 30, 761-775. doi:10.1080/01446193.2012.694457

Montel, B., Debailleul, G., 2004. Pig farming and the environmental performance of polluting products to green consumers. Les systèmes Prod. Agric. Performances, évolutions, Perspect.

Moon, S., Bae, S., Jeong, M.-G., 2014. Corporate Sustainability and Economic Performance: an Empirical Analysis of a Voluntary Environmental Program in the USA. Bus. Strateg. Environ. 23, 534-546. doi:10.1002/bse.1800

Murillo-Luna, J.L., Garcés-Ayerbe, C., Rivera-Torres, P., 2008. Why do patterns of environmental response differ? A stakeholders’ pressure approach. Strateg. Manag. J. 29, 1225-1240. 
doi:10.1002/smj.711

Podsakoff, P.M., MacKenzie, S.B., Lee, J.-Y., Podsakoff, N.P., 2003. Common method biases in behavioral research: a critical review of the literature and recommended remedies. J. Appl. Psychol. 88, 879-903. doi:10.1037/0021-9010.88.5.879

Podsakoff, P.M., Organ, D.W., 1986. Self-Reports in Organizational Research: Problems and Prospects. J. Manage. 12, 531-544. doi:10.1177/014920638601200408

Porter, M.E., 1991. America’s Green Strategy. Sci. Am. 264, 168.

Porter, M.E., Van der Linde, C., 1995a. Toward a new conception of the environmentcompetitiveness relationship. J. Econ. Perspect. 9, 97-118.

Porter, M.E., Van der Linde, C., 1995b. Green and competitive: ending the stalemate. Harv. Bus. Rev. 73, 120-134.

Post, J.E., Altman, B.W., 1994. Managing the environmental change process: barriers and opportunities. J. Organ. Chang. Manag. 7, 64-81. doi:10.1108/09534819410061388

Rivera-Torres, P., Garcés-Ayerbe, C., Scarpellini, S., Valero-Gil, J., 2015. Pro-Environmental Change and Short- to Mid-Term Economic Performance: The Mediating Effect of Organisational Design Change. Organ. Environ. 28, 307-327. doi:10.1177/1086026615603867

Ronnenberg, S.K., Graham, M.E., Mahmoodi, F., 2011. The important role of change management in environmental management system implementation. Int. J. Oper. Prod. Manag. 31, 631-647. doi:10.1108/01443571111131971

Roome, N., 1992. Developing environmental management strategies. Bus. Strateg. Environ. 1, 1124. doi:10.1002/bse.3280010104

Russo, M. V., 2009. Explaining the impact of ISO 14001 on emission performance: a dynamic capabilities perspective on process and learning. Bus. Strateg. Environ. 18, 307-319. doi:10.1002/bse.587

Schaefer, A., Harvey, B., 1998. Stage models of corporate "greening”: a critical evaluation. Bus. Strateg. Environ. 7, 109-123. doi:10.1002/(SICI)1099-0836(199807)7:3<109::AIDBSE150>3.0.CO;2-0 
Segarra-Oña, M.-V., Peiró-Signes, A., Cervelló-Royo, R., 2015. A Framework to Move Forward on the Path to Eco-innovation in the Construction Industry: Implications to Improve Firms' Sustainable Orientation. Sci. Eng. Ethics 21, 1469-1484. doi:10.1007/s11948-014-9620-2

Winn, M., Angell, L., 2000. Towards a process model of corporate greening. Organ. Stud. 21, 1119-1147. doi:10.1177/0170840600216005 